\title{
Changes in tissue abundance and activity of enzymes related to branched- chain amino acid catabolism in dairy cows during early lactation
}

\author{
L. A. Webb, ${ }^{1}$ H. Sadri, ${ }^{2 *}$ † D. von Soosten, ${ }^{3}$ S. Dänicke, ${ }^{3}$ S. Egert, ${ }^{4}$ P. Stehle,${ }^{4}$ and H. Sauerwein ${ }^{1}$ \\ ${ }^{1}$ Institute of Animal Science, Physiology and Hygiene Unit, University of Bonn, 53115 Bonn, Germany \\ ${ }^{2}$ Department of Clinical Science, Faculty of Veterinary Medicine, University of Tabriz, 516616471 Tabriz, Iran \\ ${ }^{3}$ Institute of Animal Nutrition, Friedrich-Loeffler-Institut, Federal Research Institute for Animal Health, 38116 Brunswick, Germany \\ ${ }^{4}$ Department of Nutrition and Food Sciences, Nutritional Physiology, University of Bonn, 53115 Bonn, Germany
}

\section{ABSTRACT}

Branched-chain $\alpha$-keto acid dehydrogenase (BCKDH) complex catalyzes the irreversible oxidative decarboxylation of branched-chain $\alpha$-keto acids. This reaction is considered as the rate-limiting step in the overall branched-chain amino acid (BCAA) catabolic pathway in mammals. For characterizing the potential enzymatic involvement of liver, skeletal muscle, adipose tissue (AT), and mammary gland (MG) in BCAA metabolism during early lactation, tissue and blood samples were examined on d 1, 42, and 105 after parturition from 25 primiparous Holstein cows. Serum BCAA profiles were analyzed and the mRNA and protein abundance as well as the activity in the different tissues were assessed for the BCAA catabolic enzymes, partly for the branched-chain aminotransferase and completely for BCKDH. Total BCAA concentration in serum was lowest on d 1 after parturition and increased thereafter to a steady level for the duration of the experiment. Pronounced differences between the tissues were observed at all molecular levels. The mRNA abundance of the mitochondrial isoform of branched-chain aminotransferase $(B C A T m)$ was greatest in AT as compared with the other tissues studied, indicating that AT might be an important contributor in the initiation of BCAA catabolism in dairy cows. From the different subunits of the BCKDH E1 component, only the mRNA for the $\beta$ polypeptide $(B C K D H B)$, not for the $\alpha$ polypeptide $(B C K D H A)$, was elevated in liver. The BCKDHA mRNA abundance was similar across all tissues except muscle, which tended to lower values. Highest BCKDHA protein abundance was observed in both liver and $\mathrm{MG}$, whereas BCKDHB protein was detectable in these tissues but could not be quantified. Adipose tissue and

Received January 17, 2018.

Accepted November 28, 2018.

*Corresponding author: sadri@tabrizu.ac.ir

$\dagger$ H. Sadri was a visiting scientist at the Institute of Animal Science, Physiology and Hygiene Unit, University of Bonn, 53115 Bonn, Germany, at the time the research was done. muscle only displayed abundance of the $\alpha$ subunit, with muscle having the lowest BCKDHA protein of all tissues. We found similarities in protein abundance for both BCKDH E1 subunits in liver and MG; however, the corresponding overall BCKDH enzyme activity was 7-fold greater in liver compared with $\mathrm{MG}$, allowing for hepatic oxidation of BCAA transamination products. Reduced BCKDH activity in MG associated with no measurable activity in AT and muscle may favor sparing of BCAA for the synthesis of the different milk components, including nonessential AA. Deviating from previously published data on BCAA net fluxes and isotopic tracer studies in ruminants, our observed results might in part be due to complex counter-regulatory mechanisms during early lactation.

Key words: branched-chain amino acid metabolism, branched-chain aminotransferase, branched-chain $\alpha$-keto acid dehydrogenase, tissue abundance/activity

\section{INTRODUCTION}

The 3 branched-chain AA (BCAA), Ile, Leu, and Val, represent about $30 \%$ of total AA taken up by the bovine mammary gland (MG; Cant et al., 1993; Metcalf et al., 1996). The BCAA fulfil numerous metabolic functions; that is, as precursors for NEAA, as substrates for (milk) protein, as energy substrates, and as anabolic nutritional signals, regulating protein synthesis via insulin-dependent and -independent mechanisms (e.g., in muscle and mammary tissue; Bequette et al., 2002; Appuhamy et al., 2012). Homeostasis of BCAA is almost exclusively maintained at their catabolic steps.

A unique feature of BCAA catabolism in mammals is its tissue specificity; most EAA are degraded in the liver, whereas for BCAA the first catabolic step mainly occurs extrahepatically (Suryawan et al., 1998). However, subsequent catabolic steps seem to take place in liver again (Ananieva et al., 2017), necessitating substantial shuttling of BCAA and their intermediates between the periphery and liver. In this regard, degradation of BCAA (transamination or oxidative decarboxylation of 
the transamination products) has been studied in different tissues of ruminants, including the digestive tract (Pell et al., 1986; MacRae et al., 1997), liver (Lapierre et al., 2002), muscle (Pell et al., 1986; Bequette et al., 2002), and MG (Bequette et al., 1996a,b; Thivierge et al., 2002). However, previously published data on BCAA net fluxes and isotopic tracer studies in dairy cows have shown that, quantitatively, hepatic removal of BCAA (and their metabolites) is limited, as is their oxidation (Lapierre et al., 2002; Raggio et al., 2004; Larsen et al., 2015).

Another specific feature of BCAA catabolism is that the first 2 enzymes, the branched-chain aminotransferase (BCAT; EC 2.6.1.42) and the branched-chain

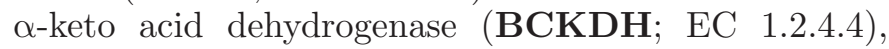
are common to all 3 BCAA. Two isoforms of BCAT are identified in mammals, with the mitochondrial BCAT (BCATm) being more abundant than the cytosolic BCAT (BCATc; Sweatt et al., 2004). Degradation begins with deamination of BCAA, catalyzed by both BCAT isoforms, resulting in the respective branched-chain $\alpha$-keto acids (BCKA; keto-isoleucine, keto-leucine, keto-valine) and glutamate. The ensuing oxidative decarboxylation of the BCKA to branchedchain acyl-CoA derivatives occurs via the E1 component of the mitochondrial BCKDH complex. Unlike BCAT, BCKDH works irreversibly and is considered rate-limiting (Harper et al., 1984). After decarboxylation, the catabolic pathways for each of the BCAA diverge, ultimately leading to glucogenic or ketogenic precursors.

During lactation, whole-body BCAA catabolism is enhanced and BCAA are used to partially cover the increased energetic and nutritional needs of the tissues, especially the MG (Li et al., 2009). Studies on the actual BCAA catabolism enzymes in ruminants are sparse. However, flux studies in ruminants have shown that the lactating MG itself catabolizes significant amounts of BCAA (Wohlt et al., 1977; Bequette et al., 1996a). Based on $\mathrm{BW}$, the relative rates of $\mathrm{BCAA}$ deamination and BCKA oxidation by the MG are much higher than those of the hind leg muscle (Bequette et al., 2002), likely favoring BCAA metabolism by the MG.

Besides storing lipids, adipose tissue (AT) is known to be endocrine gland regulating; for example, in glucose and lipid homeostasis through adipokine secretion. Nevertheless, its role in systemic protein and AA metabolism has not been widely studied, particularly in ruminants. Herman et al. (2010) reported the potential capacity for AT to regulate circulating BCAA levels in vivo. Those authors demonstrated that transplantation of wild-type AT into mice globally defective in peripheral BCAA metabolism reduced their circulating BCAA levels by 30 and $50 \%$ in the fasted and fed states, respectively. Assessing BCAA metabolism in AT via flux studies, as done for MG, liver, and muscle, is hardly possible due to the multiple locations of AT and the heterogeneity of function in different depots. Hence, in the current study, we aimed to test the potential enzymatic capacity of AT (alongside liver, muscle, and $\mathrm{MG}$ ) in BCAA metabolism in dairy cows during early lactation. We hypothesized that (1) early lactation is associated with tissue-specific changes in the key enzymes of BCAA metabolism due to particular metabolic adaptations and that (2) BCAA enzymes in AT contribute significantly to the degrading pathway. Studying the changes in abundance and activity of BCAA catabolic enzymes in different tissues of dairy cows during early lactation in more detail would allow for estimating their importance in the adaptive processes.

\section{MATERIALS AND METHODS}

\section{Animals and Sample Collection}

Different tissues [i.e., liver, skeletal muscle, MG, subcutaneous (scAT) and visceral adipose tissue (vAT)] as well as blood samples were obtained from 25 primiparous German Holstein cows (mean \pm SD age at first calving $=23 \pm 0.2 \mathrm{mo}$ ) at 3 different slaughter time points: d 1, 42, and 105 after parturition. The animals were part of a comprehensive study conducted at the Friedrich-Loeffler-Institut, Federal Research Institute for Animal Health (Brunswick, Germany), on the effect of dietary CLA on performance and changes in body composition, including body fat and protein, and on energy utilization during early lactation (von Soosten et al., 2011, 2012). On the day after parturition, 5 animals were euthanized, whereas the remaining 20 cows were assigned to either a control $(100 \mathrm{~g} / \mathrm{d}$ of stearic acid; Silafat, BASF SE, Ludwigshafen, Germany; $\mathrm{n}=10$ ) or CLA-supplemented diet $(100 \mathrm{~g} / \mathrm{d} ; 1.7 \%$ trans-10, cis- 12 , 1.6\% cis-9,trans-11 CLA isomers; Lutrell Pure, BASF $\mathrm{SE} ; \mathrm{n}=10)$. Five cows per group were then slaughtered at d 42 and 105. The CLA supplementation did not significantly affect any of the herein examined variables; thus, and to increase the statistical power, treatment groups at the respective slaughter time points were pooled as d $1(\mathrm{n}=5), 42(\mathrm{n}=10)$, and $105(\mathrm{n}=10)$.

All protocols of the study were designed and performed in strict accordance with the European Union guidelines, established by the European Community Council Directives 86/609/EEC (European Council, 1986), concerning the protection of experimental animals, with approval by the Lower Saxony State Office for Consumer Protection and Food Safety (LAVES), Oldenburg, Germany (File Number 33.11.42502-04- 
071/07). Animals were kept in group pens in a freestall barn with free access to water. The partial mixed ration fed prepartum consisted of $60 \%$ corn silage and $40 \%$ grass silage (6.7 MJ of $\mathrm{NE}_{\mathrm{L}} / \mathrm{kg}$ of $\mathrm{DM}$ ) on a DM basis for ad libitum consumption and $2 \mathrm{~kg}$ of concentrate $(6.7$ MJ of $\mathrm{NE}_{\mathrm{L}} / \mathrm{kg}$ of $\left.\mathrm{DM}\right)$. Postpartum, cows received a partial mixed ration of $25 \%$ corn silage and $38 \%$ grass silage (7.5 MJ of $\mathrm{NE}_{\mathrm{L}} / \mathrm{kg}$ of $\mathrm{DM}$ ) and $37 \%$ concentrate (8.7 MJ of $\mathrm{NE}_{\mathrm{L}} / \mathrm{kg}$ of $\mathrm{DM}$ ) on a DM basis for ad libitum intake as well as an additional $3.5 \mathrm{~kg}$ of concentrate containing the respective rumen-protected CLA or control fat supplements. The additional 2 and $3.5 \mathrm{~kg}$ of concentrate were fed via a computerized concentrate feeding station (RIC; Insentec B.V., Marknesse, the Netherlands). All diets were formulated according to the recommendations of the German Society of Nutrition Physiology (GfE, 2001). A detailed description of the ingredients as well as the composition of the diets can be found in von Soosten et al. (2011). Postcalving, daily individual feed intake was recorded automatically (RIC; Insentec B.V.) from wk 2 to 15 after the start of lactation. Cows were milked twice daily (LemmerFullwood, Lohmar, Germany) with automatic recordings of milk yield. Milk samples were taken twice per week and stored at $4^{\circ} \mathrm{C}$ until analysis.

Right before slaughter, blood samples were taken via jugular venipuncture. Serum was obtained after clotting and centrifugation $\left(3,000 \times g, 10 \mathrm{~min}, 4^{\circ} \mathrm{C}\right)$ and stored at $-80^{\circ} \mathrm{C}$ until analysis. Samples of liver, skeletal muscle (semitendinosus muscle), MG (udder parenchyma), scAT (tail head), and vAT (omental fat) were collected after slaughter, rinsed with $0.9 \% \mathrm{NaCl}$, and immediately snap-frozen in liquid nitrogen and stored at $-80^{\circ} \mathrm{C}$ for the respective extractions and analyses.

\section{Milk and Blood Analyses}

Milk composition was assessed using an infrared milk analyzer (Milkoscan FT 6000 combined with a Fossomatic 5000, Foss Electric, Hillerød, Denmark). Serum BCAA concentrations were measured via HPLC in an RF-10A XL fluorescence detector (Shimadzu, Kyoto, Japan) based on o-phtaldialdehyde/3-mercaptopropionic acid derivatization as previously described (Fürst et al., 1990). Inter- and intra-assay variances were $<5 \%$.

\section{RNA Extraction and Quantitative Real-Time Reverse Transcription-PCR}

Total RNA extraction and cDNA synthesis were conducted as described by Saremi et al. (2012a). Analysis by quantitative real-time reverse transcription PCR (qPCR) was carried out in accordance with the Minimum Information for Publication of Quantita- tive Real-Time PCR Experiments (MIQE) guidelines (Bustin et al., 2009) using the sample maximization method. Triplicates were run in a total volume of 10 $\mu \mathrm{L}$, with $2 \mu \mathrm{L}$ of cDNA (diluted 1:4) as template, 1 $\mu \mathrm{L}$ of assay-specific primer mix, $2 \mu \mathrm{L}$ of water, $5 \mu \mathrm{L}$ of DyNAmo ColorFlash SYBR Green qPCR Kit (Thermo Fisher Scientific, Dreireich, Germany) for the target genes branched-chain aminotransferase, mitochondrial $(B C A T m)$, branched-chain $\alpha$-keto acid dehydrogenase E1, a polypeptide $(B C K D H A)$, and branched-chain $\alpha$-keto acid dehydrogenase E1, $\beta$ polypeptide $(B C K$ $D H B)$, or $5 \mu \mathrm{L}$ of SYBR Green JumpStart Taq Readymix (Sigma-Aldrich, Steinheim, Germany) for the reference genes; analysis was carried out in Mx3000P cycler systems (1 from Stratagene, Amsterdam, the Netherlands, and 1 from Agilent, Santa Clara, CA). Each run included a negative template control, a noreverse-transcriptase control as well as 2 inter-run calibrators prepared from plate-specific pool samples. Quantification of the samples was performed against a cDNA standard curve with serial dilutions for the target genes and against a PCR product standard curve with serial dilutions for the reference genes. Target genes were normalized with the most stable reference genes, namely emerin $(E M D)$, hippocalcin-like 1 (HPCAL1), eukaryotic translation initiation factor 3 (EIF3K), RNA polymerase II (POLR2A), and lipoprotein receptor-related protein 10 (LRP10), which were previously selected from a set of 9 genes according to Saremi et al. (2012b). Reference genes were evaluated based on their average expression stability $(\mathrm{M})$ and pairwise variation $(\mathrm{V})$ values (accepted $\mathrm{M}<1.5$ and $\mathrm{V}<0.15)$ using the geNorm ${ }^{\text {PLUS }}$ algorithms of qBase ${ }^{\text {PLUS }} 2.1$ software (Biogazelle, Ghent, Belgium). Primer sequences as well as qPCR conditions were the same for a given gene in all tissues and are provided in Table 1.

\section{Quantification of Target Proteins}

Tissue samples were homogenized in ice-cold Tris/ $\mathrm{HCl}$ lysis buffer ( $\mathrm{pH}$ 7.4) containing protease inhibitors cOmplete, Mini Protease Inhibitor Cocktail, 1 tablet per $10 \mathrm{~mL}$; Roche Diagnostics, Mannheim, Germany; Pefabloc SC [4-(2-aminoethyl)benzenesulfonyl fluoride hydrochloride, $1 \mathrm{~m} M$, Sigma Aldrich, St. Louis, MO] for inhibiting serine, cysteine, and metalloproteases in a tissue-to-buffer ratio of 1:8 (liver), 1:4 (muscle and MG), or 1:2 (AT) using the Precellys 24 system (VWR/Peqlab Biotechnologie, Erlangen, Germany). Total protein concentration was measured via Bradford assay (Roti Nanoquant K880, Carl Roth, Karlsruhe, Germany).

Protein quantification was performed by Simple Western size-based protein assay (WES, Protein- 
Table 1. Characteristics of primers and real-time PCR conditions

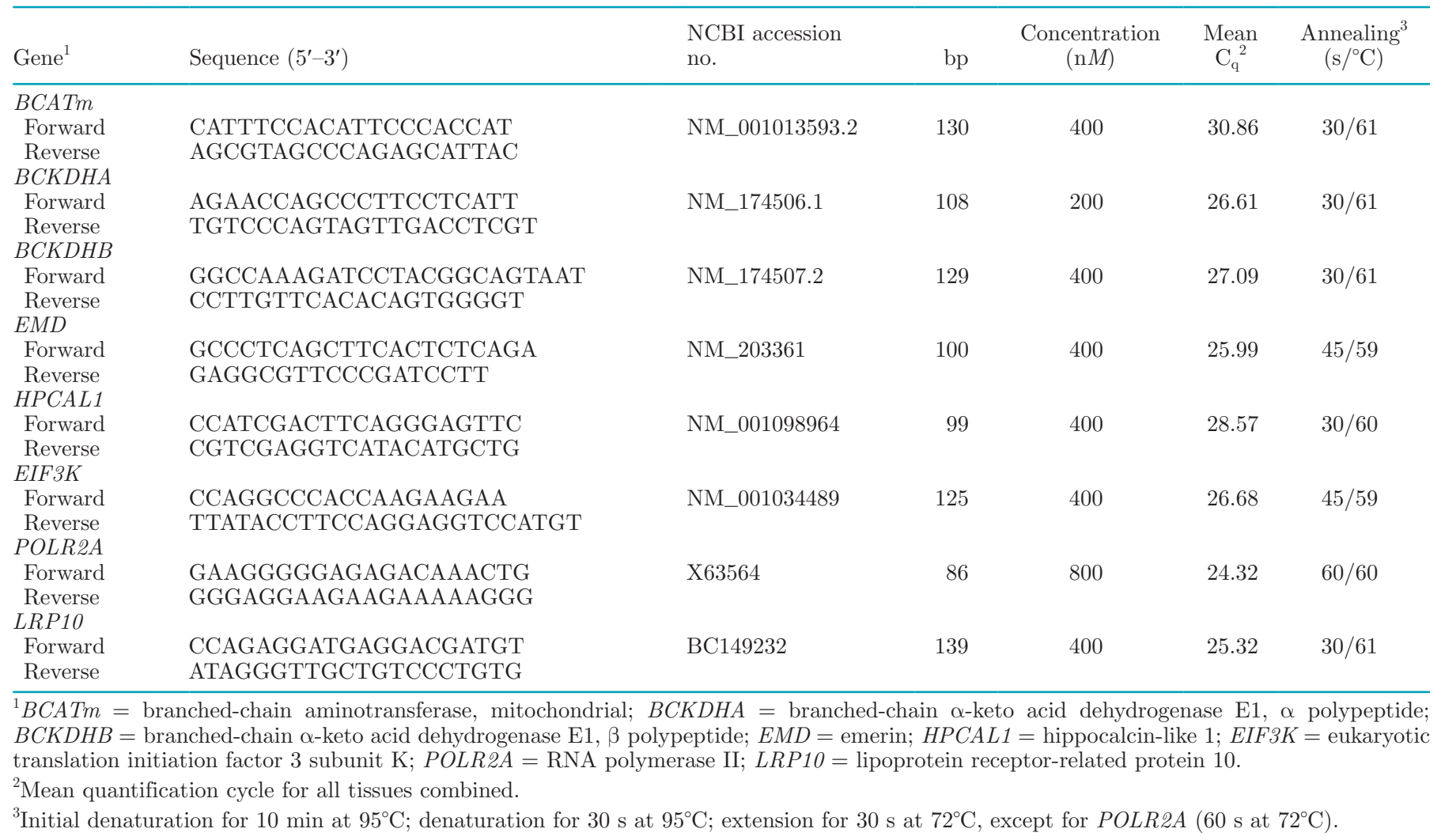

Simple, San Jose, CA), an automated capillary-based electrophoretic immunoassay, as per the manufacturer's instructions (https://www.proteinsimple.com/technical _library.html). In brief, samples were first diluted with $0.1 \times$ sample buffer to adjust the protein concentration to a dilution within the linear range (between 0.3125 and $0.9375 \mu \mathrm{g} / \mu \mathrm{L}$ depending on tissue type) and then diluted $4: 1$ by adding $2.5 \mu \mathrm{L}$ of the $5 \times$ master mix. The final samples were heated for $5 \mathrm{~min}$ at $95^{\circ} \mathrm{C}$, placed on ice for $5 \mathrm{~min}$, briefly centrifuged twice $(2,500 \times g, 5 \mathrm{~s}$, $20^{\circ} \mathrm{C}$ ) with short vortex spins in between, and applied to the wells in duplicates. A control sample (bovine liver) was also loaded on every plate to correct for inter-run variations (accepted interassay CV $<10 \%$, intra-assay $\mathrm{CV}<8 \%$ ). Primary antibodies against total BCKDHA (\#ab138460; Abcam, Cambridge, UK) and total BCKDHB (\#ab182255; Abcam) were diluted 1:50 and 1:25, respectively. All other reagents (antibody diluent, secondary antibodies, streptavidin-HRP, luminol-S, hydrogen peroxide) loaded on the plate were obtained from ProteinSimple and used according to the recommendations. Simple Western analysis was performed with multi-image exposures and otherwise instrument default settings at room temperature (RT). Using Compass Software (ProteinSimple), the area under the curve, which represents the signal intensity of the chemiluminescent immunoreaction, and which directly correlates with the abundance of the target protein, was assessed for each sample and normalized to the control.

\section{Enzyme Activity}

Enzyme activity of the BCKDH complex was determined spectrophotometrically in a Synergy H1 microplate reader (BioTek, Winooski, VT) according to Nakai et al. (2000). Approximately $100 \mathrm{mg}$ of frozen tissue were homogenized (Precellys 24) in 1,200 $\mu \mathrm{L}$ of ice-cold extraction buffer. After removing insoluble material by centrifugation $\left(20,000 \times g, 5 \mathrm{~min}, 4^{\circ} \mathrm{C}\right)$, the supernatant was incubated with $27 \%$ (wt/vol) polyethylene glycol for $20 \mathrm{~min}$ on ice. Following a second centrifugation step $\left(12,000 \times g, 10 \mathrm{~min}, 4^{\circ} \mathrm{C}\right)$, the pellet was dissolved in a suspension buffer by pipetting up and down while keeping the sample on ice. Protein concentrations of the prepared homogenates were assessed with Bradford assay (Roti Nanoquant K880, Carl Roth) and the activity assay was performed directly afterward. For this, samples were diluted 1:10 with $2 \times$ assay buffer and sterile water to a volume of $1 \mathrm{~mL}$. Before adding the homogenate, the buffer-water mixture was preheated to $30^{\circ} \mathrm{C}$ and $200 \mu \mathrm{L}$ of the final assay-mixture was then 
loaded onto 96 -well polystyrene microplates. The absorbance at $340 \mathrm{~nm}$ and $30^{\circ} \mathrm{C}$ was recorded for $5 \mathrm{~min}$ to establish a baseline and the reaction was initiated with $20 \mu \mathrm{L}$ of $10 \mathrm{~m} M \alpha$-ketoisovalerate (final concentration $1 \mathrm{mM}$ ) as substrate prewarmed to $30^{\circ} \mathrm{C}$. In contrast to Nakai et al. (2000), the assay buffer was prepared without exogenous dihydrolipoamide dehydrogenase, as validated by Wessels et al. (2016). A control sample (bovine liver) with comparable BCKDH activity was included on each plate for inter-run calibration (accepted interassay CV $<15 \%$, intra-assay CV $<5 \%$ ) and sample data were normalized to the control.

\section{Statistical Analyses}

In case of the mRNA data, final results were calculated by qBase ${ }^{\text {PLUS }}$ (i.e., the calibrated normalized relative quantities values were used for statistical analysis of the data). Statistical analysis was carried out with SPSS 24 (IBM, Armonk, NY). Before analysis, data were tested for normal distribution and, when necessary (in case of mRNA data), $\log _{10}$ transformed. All analyses were conducted with the different dietary treatments in the respective model at first. Due to nonsignificance and an increase in statistical power, groups were combined in the final models given below.

Data for performance and serum BCAA were analyzed as repeated measures using a linear mixed model and Bonferroni post hoc tests for correcting multiple comparisons:

$$
\mathrm{Y}_{\mathrm{ij}}=\mu+\mathrm{cow}_{\mathrm{i}}+\text { time }_{\mathrm{j}}+\mathrm{e}_{\mathrm{ij}} \text {, }
$$

where $Y_{\mathrm{ij}}=$ response variable, $\mu=$ overall mean, cow $\mathrm{i}_{\mathrm{i}}$ $=$ random effect of cow $(\mathrm{i}=1$ to 25$)$, time $_{\mathrm{j}}=$ fixed effect of sampling time $(\mathrm{j}=$ wk 2 to 15 of lactation and d 1, 42, or 105 after parturition, respectively), and $\mathrm{e}_{\mathrm{ij}}$ $=$ residual error.

Data concerning mRNA and protein abundance as well as enzyme activity were evaluated using a linear mixed model and Bonferroni correction according to the following equation:

$$
\begin{gathered}
\mathrm{Y}_{\mathrm{ijk}}=\mu+\text { cow }_{\mathrm{i}}+\text { tissue }_{\mathrm{j}}+\text { time }_{\mathrm{k}}+\text { tissue }_{\mathrm{j}} \\
\times \text { time }_{\mathrm{k}}+\mathrm{e}_{\mathrm{ijk}},
\end{gathered}
$$

where $Y_{\mathrm{ijk}}=$ response variable, $\mu=$ overall mean, cow $_{\mathrm{i}}$ $=$ random effect of cow $(\mathrm{i}=1$ to 25$)$, tissue $_{\mathrm{j}}=$ fixed effect of tissue type ( $\mathrm{j}=$ liver, muscle, $\mathrm{MG}, \mathrm{scAT}, \mathrm{vAT})$, time $_{\mathrm{k}}=$ fixed effect of sampling time $(\mathrm{k}=\mathrm{d} 1,42$, or 105 after parturition), tissue $_{\mathrm{j}} \times$ time $_{\mathrm{k}}=$ fixed tissue $\times$ time interaction, and $\mathrm{e}_{\mathrm{ijk}}=$ residual error.
Data are expressed as means \pm standard error of the means. Level of significance was set at $P<0.05$. Trends were declared at $0.05<P \leq 0.10$.

\section{RESULTS}

\section{Animal Performance}

A detailed description of animal performance was reported by von Soosten et al. (2011). No significant differences between the treatment groups were observed in the performance parameters described in the current study; thus, data were merged for analysis of time effects (Figure 1). In brief, as expected, DMI changed over time $(P<0.001)$ and increased with week in milk (wk 2 versus all subsequent time points; $P<0.05$ ). Milk yield reached a plateau around wk 4 after parturition. During peak lactation, cows yielded, on average, $27.5 \pm$ $1.0 \mathrm{~kg}$ of milk and $0.86 \pm 0.02 \mathrm{~kg}$ of milk protein.

\section{Serum BCAA Concentrations}

The CLA supplementation did not affect BCAA concentrations in serum. Concentrations of Leu were not affected by time $(P=0.18$; Figure 2a), whereas concentrations of Ile and Val showed significant differences between the 3 time points $(P<0.001$ and $P=$ 0.001; Figure 2b and 2c, respectively). For Ile and Val, concentrations increased from d $1(68 \pm 14$ and $138 \pm$ $48 \mu M)$ to $42(180 \pm 17$ and $337 \pm 21 \mu M$; both $P=$ $0.001)$.

Serum concentrations of total BCAA (calculated as the sum of Leu, Ile, and Val) changed over time $(P=$ 0.002; Figure 2d). The lowest concentrations, $298 \pm 92$ $\mu M$, were observed on $\mathrm{d} 1$ after parturition, which then increased to $652 \pm 47 \mu M$ on d $42(P=0.002)$. From d 42 to 105 after parturition, all BCAA concentrations remained unaltered.

\section{mRNA Abundance of BCAA Key Enzymes}

The mRNA abundance of the enzymes related to BCAA catabolism did not differ between the 2 treatment groups. The BCATm mRNA abundance varied with tissue type and sampling time $(P<0.001$ and $P$ $=0.01$, respectively; Figure 3), whereby interactions between these factors were observed $(P=0.01)$. Within tissues, we also noted time effects; that is, for scAT and vAT, BCATm mRNA abundance was lowest on $\mathrm{d} 1$ and increased more than 3-fold until d 105 after parturition (both $P=0.02$ ). For direct tissue comparisons, data from the different time points were merged, and 

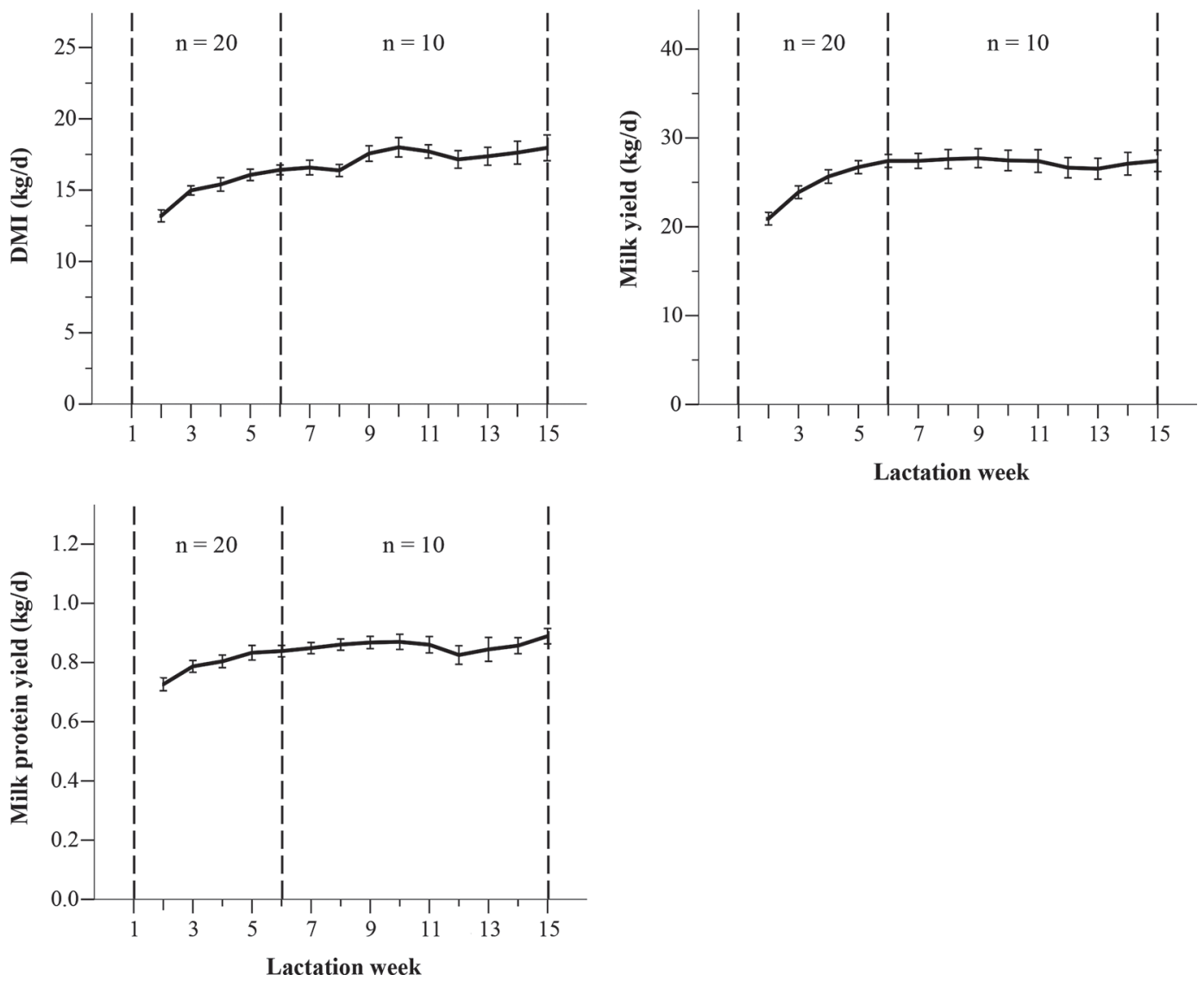

Figure 1. Weekly DMI, milk yield, and milk protein yield of cows during the experimental period. Data are given as means \pm SEM. Dashed lines indicate slaughtering time points (d 1, 42, and 105 after parturition).

BCATm mRNA was around 4 times greater in both fat depots compared with corresponding abundances in liver, muscle, and MG $(P<0.001)$.

The mRNA abundance of $B C K D H A$ was overall significantly influenced by tissue $(P<0.001)$ and time $(P=0.001)$, but we found no interaction of tissue $\times$ time $(P=0.63$; Figure 4$)$. Muscle tissue had the lowest $B C K D H A$ mRNA, whereas liver, MG, and scAT possessed higher (all $P<0.05$ ) yet similar abundance among each other. We observed an increase of $B C K$ DHA mRNA over time in MG and in vAT, with the lowest values on $\mathrm{d} 1$ followed by a continuous increase until d $105(P=0.01$ and $P=0.03$, respectively).

Tissue type and time both affected $B C K D H B$ mRNA abundance $(P<0.001, P=0.01$, respectively; Figure $5)$, but we observed no interaction of tissue $\times$ time $(P$ $=0.78$ ). The $B C K D H B$ mRNA abundance was around 5 times greater in liver than in any of the other tissues tested (each $P<0.001$ ). Within MG, $B C K D H B$ mRNA abundance increased steadily from d 1 to $105(P=$ $0.02)$. For vAT, we noted a trend for an increase from d 1 to $105(P=0.06)$.

\section{Protein Abundance of the BCKDH E1 Subunits}

No differences related to the CLA supplementation were observed for the protein abundance of the BCKDH E1 subunits. Total BCKDHA protein abundance was affected by tissue type $(P<0.001)$, but not by time $(P=0.07)$; however, the interaction of tissue $\times$ time was significant $(P=0.01$; Figure 6$)$. Liver and MG expressed BCKDHA the most, followed by the 2 AT and then muscle. For MG and both AT separately, partially significant but irregular changes in BCKDHA protein over time could be detected.

Total BCKDHB protein was qualitatively detected in liver and $\mathrm{MG}$, but not in muscle or AT (data not shown). However, quantification of BCKDHB protein in liver and MG was not possible due to lack of antibody saturation.

\section{Activity of the BCKDH Complex}

The activity of the whole BCKDH complex was not influenced by the CLA treatment. Even so, enzyme 

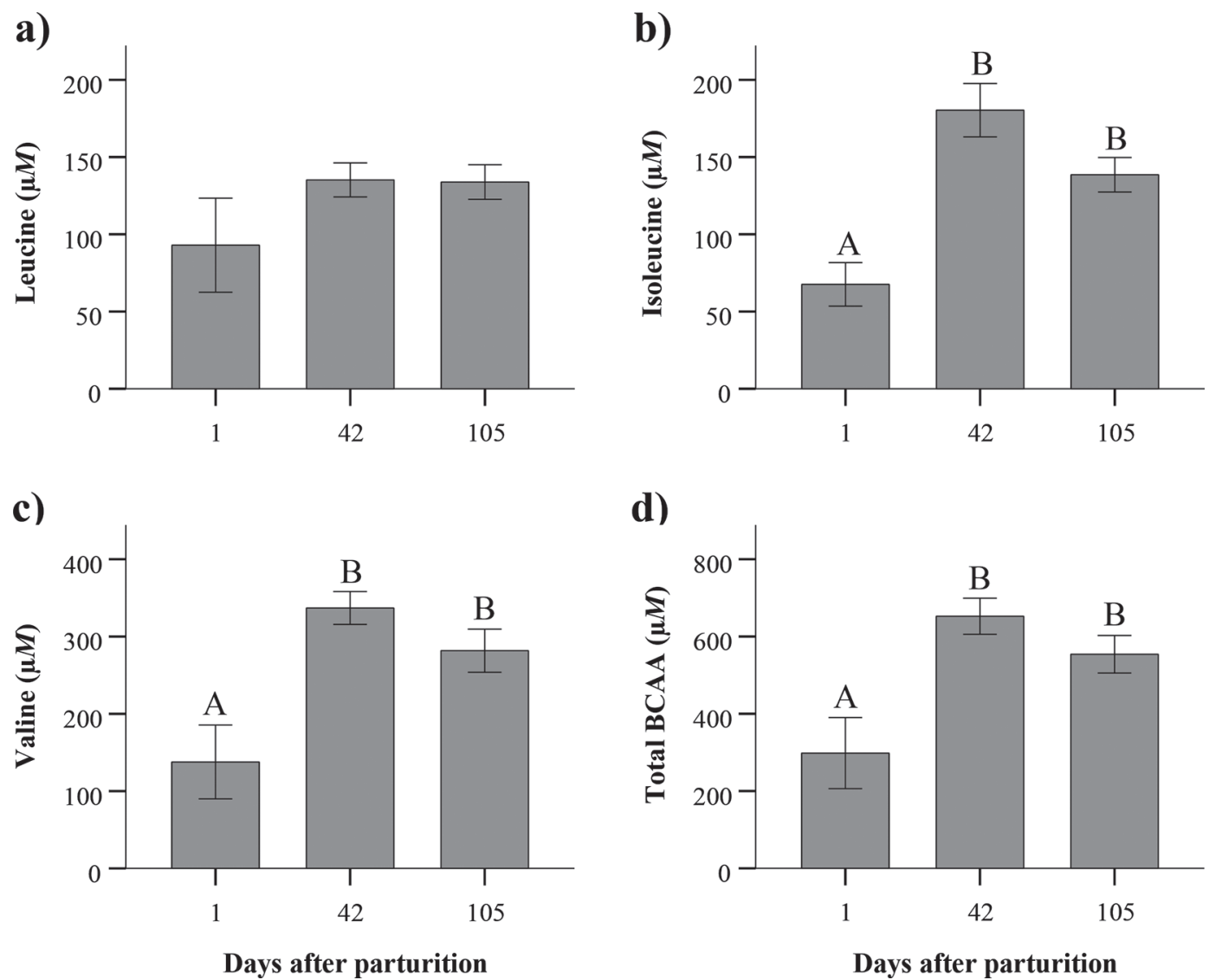

Figure 2. Serum concentrations of leucine (a), isoleucine (b), valine (c), and total branched-chain amino acids (BCAA; d) in dairy cows on $\mathrm{d} 1(\mathrm{n}=5), 42(\mathrm{n}=10)$, and $105(\mathrm{n}=10)$ after parturition. Data are given as means \pm SEM. Different letters $(\mathrm{A}, \mathrm{B})$ indicate differences $(P<$ $0.05)$ between the 3 time points. Total BCAA are calculated as the sum of leucine, isoleucine, and valine.

activity could only be measured in liver and MG; the values for muscle and both AT were below the limit of detection. Activity of BCKDH was affected by tissue type $(P<0.001)$ and sampling time $(P=0.01)$, but we found no tissue $\times$ time interaction $(P=0.12$; Figure 7$)$. At all 3 time points, BCKDH activity was, on average, 7 -fold greater in liver as compared with MG. Further, a slight increase of $\mathrm{BCKDH}$ activity in liver from $\mathrm{d}$ 1 to 42 after parturition was observed $(P=0.02)$. In contrast, we detected no significant time-dependent changes for MG.

\section{DISCUSSION}

In this study, we aimed to investigate the potential enzymatic capacity of different tissues in BCAA metabolism in dairy cows during early lactation by analyzing the concentrations of BCAA in the circulation as well as the mRNA and protein abundance and activity of the catabolic enzymes in liver, muscle, $\mathrm{AT}$, and $\mathrm{MG}$, mainly regarding the rate-limiting key enzyme BCKDH. The CLA treatment did not affect any of those variables, probably due to the timing of the supplementation, which only started on the day after parturition. Further, the applied CLA dosage, although in the common range for the primarily targeted effect in dairy cows (i.e., milk fat reduction), might not have been sufficient for the supplements to accumulate in the body. Using the same study population, von Soosten et al. (2013) reported only marginal CLA concentrations in the tissues [e.g., $0.01 \%$ trans -10 , cis -12 CLA in scAT, vAT, MG, and offal (containing liver) of CLA-supplemented cows versus no detectable CLA in the control group; contents in muscle were below the limit of detection for both groups] and, in case of the cis-9,trans-11 CLA isomer, no change in the amount of CLA because of supplementation. In summary, it can be assumed that because of the overall low transfer of the supplemented isomers into the body, the CLA treatment was not effective enough to elicit a response at tissue level and, thus, affect BCAA metabolism.

Concerning the tissue distribution of BCAA catabolic enzymes, the current literature is quite ambiguous and is mainly based on studies in nonruminants. To 


\section{BCATm}

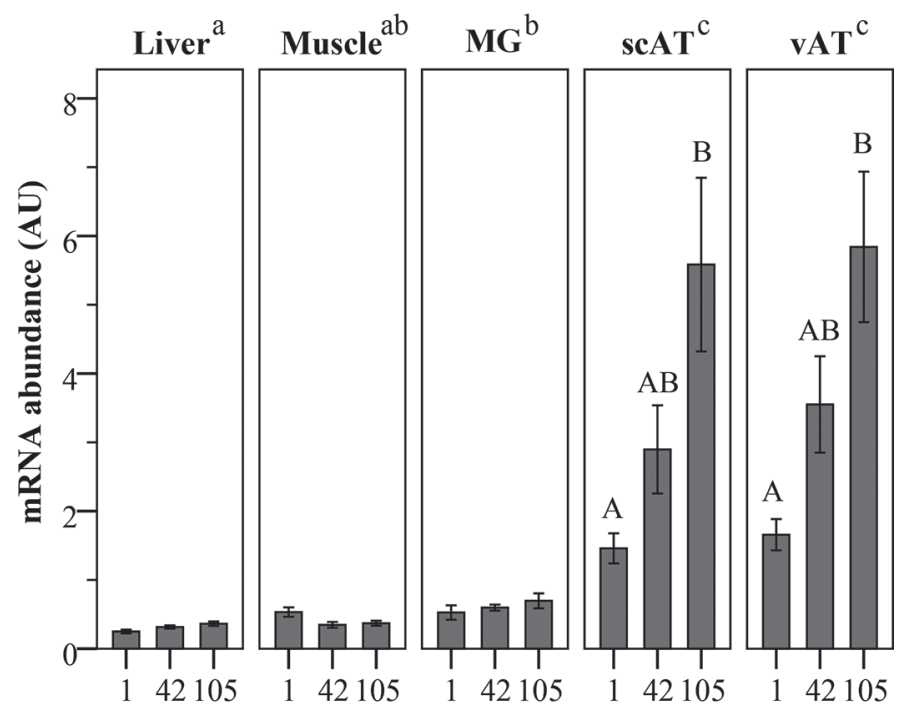

Days after parturition

Figure 3. The mRNA abundance (arbitrary units; AU) of the mitochondrial branched-chain aminotransferase $(B C A T m)$ in liver, skeletal muscle, mammary gland (MG), and subcutaneous (scAT) and visceral adipose tissue (vAT) of dairy cows on d $1(\mathrm{n}=5), 42(\mathrm{n}=$ $10)$, and $105(\mathrm{n}=10)$ after parturition. Data are given as means \pm SEM. Different lowercase letters $(\mathrm{a}-\mathrm{c})$ indicate differences $(P<0.05)$ between tissues; different uppercase letters $(\mathrm{A}, \mathrm{B})$ indicate differences $(P<0.05)$ between time points within one tissue.

our knowledge, this is the first report on tissue-specific differences in abundance as well as activity of BCAA key enzymes in dairy cows, allowing for estimating the importance of different tissues in the adaptive processes occurring during early lactation.

It is likely that the observed lower BCAA concentrations on d 1 after parturition were due to reduced feed intake before calving, which is described in several publications (e.g., Grummer, 1995). In our study, DMI could only be recorded from the second week of lactation onwards; nevertheless, DMI was still lower at wk 2 compared with all subsequent time points. Moreover, metabolic stress, related to the negative energy balance during the transition from late pregnancy to lactation, is associated with an increase in positive acute phase proteins such as serum amyloid A (Meglia et al., 2005) and haptoglobin (Saremi et al., 2012a). Both proteins, containing BCAA and in the milligrams per milliliter range close to parturition, require substantial AA supply. In addition, it is known that human immune cells oxidize BCAA in vitro to release energy and to use them for the synthesis of new cells or effector molecules (Calder, 2006).

After absorption, most EAA are degraded by the liver, whereas catabolism of BCAA seems to be under the joint control of several metabolically active tissues (Goodwin et al., 1987; Suryawan et al., 1998). Based on data from AA net fluxes and isotopic tracer studies in dairy cows, hepatic removal of BCAA (and their metabolites) has been described as greatly reduced even at high AA supply (Wray-Cahen et al., 1997; Lapierre et al., 2002; Raggio et al., 2004) both in dry and lactating animals. However, some variations in the extent of hepatic removal relative to portal absorption have been reported (Raggio et al., 2004), which variation likely due to differences in the metabolic need of AA in various physiological stages. Pell et al. (1986), using both radiolabeled Leu and keto-leucine, the deamination product of Leu, showed that around $75 \%$ of the keto-leucine released from the hindquarter, portaldrained viscera, and remaining tissues of infused sheep is oxidized in the liver, compared with only $17 \%$ in the hindquarter of fed sheep. Goodwin et al. (1987) and Papet et al. (1988) observed highest BCKDH activity in ovine liver (and kidney) compared with muscle, AT, and jejunum, demonstrating hepatic involvement in BCAA metabolism to some extent. Even if full hepatic BCKA oxidation may be relatively low, high BCKDH activity would ensure the removal of excess BCKA, which are toxic at high blood concentrations.

\section{BCKDHA}

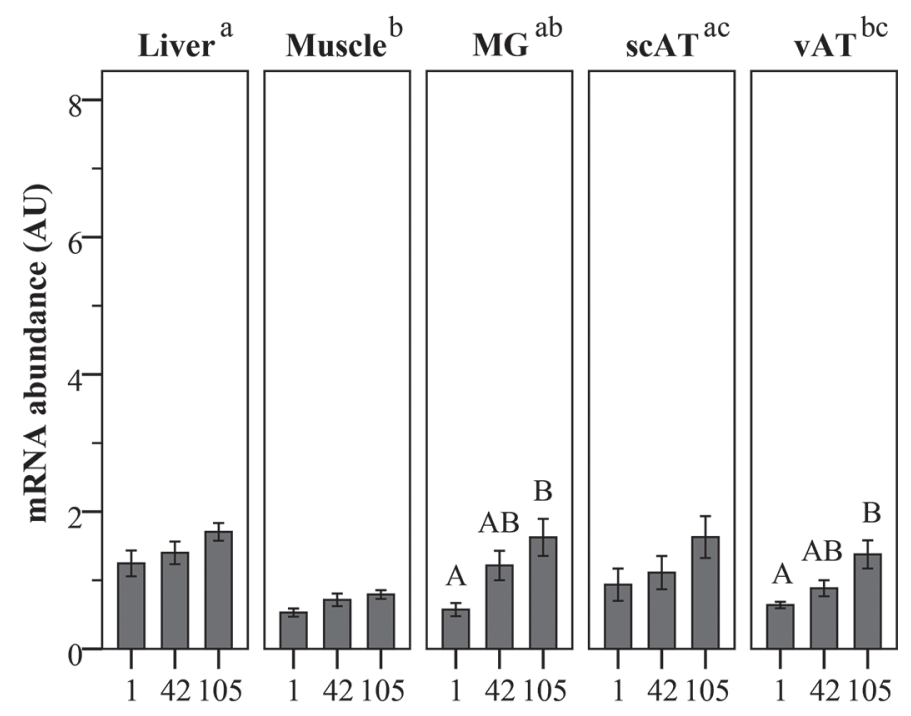

\section{Days after parturition}

Figure 4. The mRNA abundance (arbitrary units; AU) of the branched-chain $\alpha$-keto acid dehydrogenase E1, $\alpha$ polypeptide $(B C K D H A)$ in liver, skeletal muscle, mammary gland (MG), and subcutaneous (scAT) and visceral adipose tissue (vAT) of dairy cows on d $1(\mathrm{n}=5), 42(\mathrm{n}=10)$, and $105(\mathrm{n}=10)$ after parturition. Data are given as means \pm SEM. Different lowercase letters $(\mathrm{a}-\mathrm{c})$ indicate differences $(P<0.05)$ between tissues; different uppercase letters $(\mathrm{A}, \mathrm{B})$ indicate differences $(P<0.05)$ between time points within one tissue. 


\section{BCKDHB}

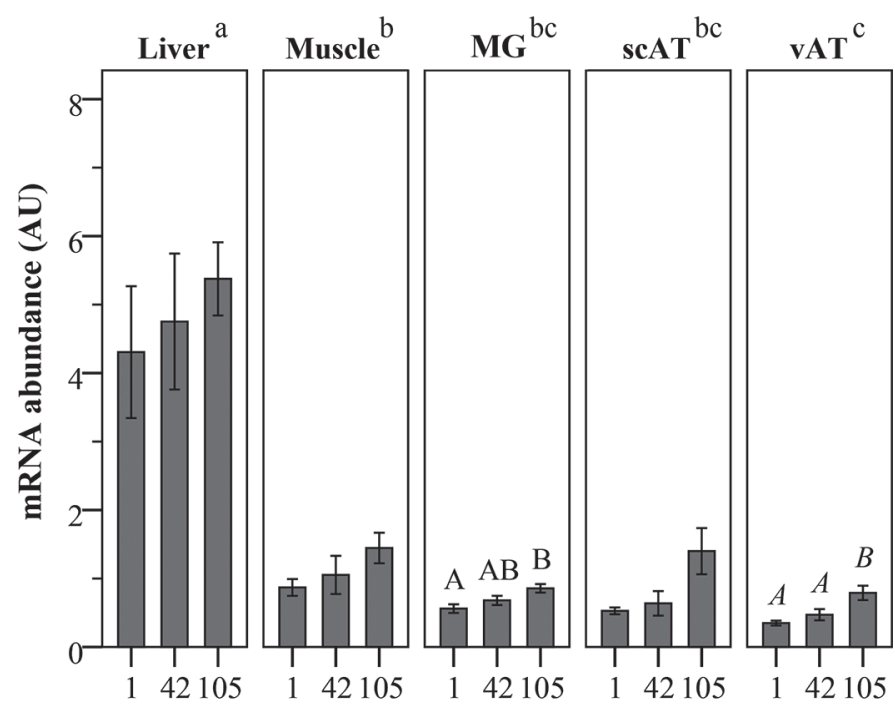

Days after parturition

Figure 5. The mRNA abundance (arbitrary units; AU) of the branched-chain $\alpha$-keto acid dehydrogenase $\mathrm{E} 1, \beta$ polypeptide $(B C K D H B)$ in liver, skeletal muscle, mammary gland (MG), and subcutaneous (scAT) and visceral adipose tissue (vAT) of dairy cows on d $1(\mathrm{n}=5), 42(\mathrm{n}=10)$, and $105(\mathrm{n}=10)$ after parturition. Data are given as means \pm SEM. Different lowercase letters $(\mathrm{a}-\mathrm{c})$ indicate differences $(P<0.05)$ between tissues; different uppercase letters $(\mathrm{A}, \mathrm{B})$ indicate differences $(P<0.05)$ between time points within one tissue, whereas italic letters indicate trends $(0.05<P<0.1)$.

In general, it has been acknowledged that the initial step in BCAA catabolism, the reversible deamination via BCAT, may occur extrahepatically [e.g., in muscle (Bequette et al., 2002), AT (Bergen et al., 1988), or MG (Bequette et al., 1996a)]. Depending on the tissue, this is followed by either the export of the resulting BCKA into the blood stream or direct oxidative decarboxylation of BCKA to acyl-CoA derivatives via $\mathrm{BCKDH}$ and, hence, not adding to the plasma flux (Lapierre et al., 2002).

In the current study, BCATm mRNA in liver was marginal, which may point to low BCAA transamination in this tissue and, consequently, a greater availability of absorbed BCAA to peripheral tissues. However, measuring mRNA cannot be used as surrogate for the corresponding protein; thus, further studies including protein abundance and activity of $\mathrm{BCAT}(\mathrm{m})$ are warranted to support our assumption.

Surprisingly, low BCATm mRNA abundance was also detected in MG and skeletal muscle. According to Mepham (1982), and confirmed in other bovine studies (e.g., Raggio et al., 2006; Larsen et al., 2014), BCAA (and Lys), arising primarily from muscle mobilization, are usually taken up in excess to their output as milk protein, even during early lactation, supporting the synthesis of NEAA as mammary uptake of NEAA is generally insufficient for milk protein synthesis. For this, at least some transamination is necessary; however, it may be possible that the decreased BCATm abundance in MG in our study was a result of a counter-effective downregulation to avoid further promotion of postpartum AA deficiencies.

Moreover, it has been reported that sheep muscle (longissimus dorsi) expresses both BCAT isoforms, $B C A T m$ and $B C A T c$, and that significant activity may be attributed to the cytosolic isoform (Faure et al., 2001). It remains to be clarified whether BCAA transamination in muscle and MG of dairy cows may also in part or even largely be mediated by $B C A T c$.

The mRNA abundance of $B C A T m$ was greatest in both scAT and vAT compared with all other tissues, which indicates that, on a transcriptional level, AT might be an important contributor in the initiation of BCAA catabolism in dairy cattle. This notion is in line with a study by Bergen et al. (1988), who showed that Leu deamination activity as well as the predicted deamination capacity based on body and tissue weights was highest in scAT compared with muscle, liver, and

\section{BCKDHA}

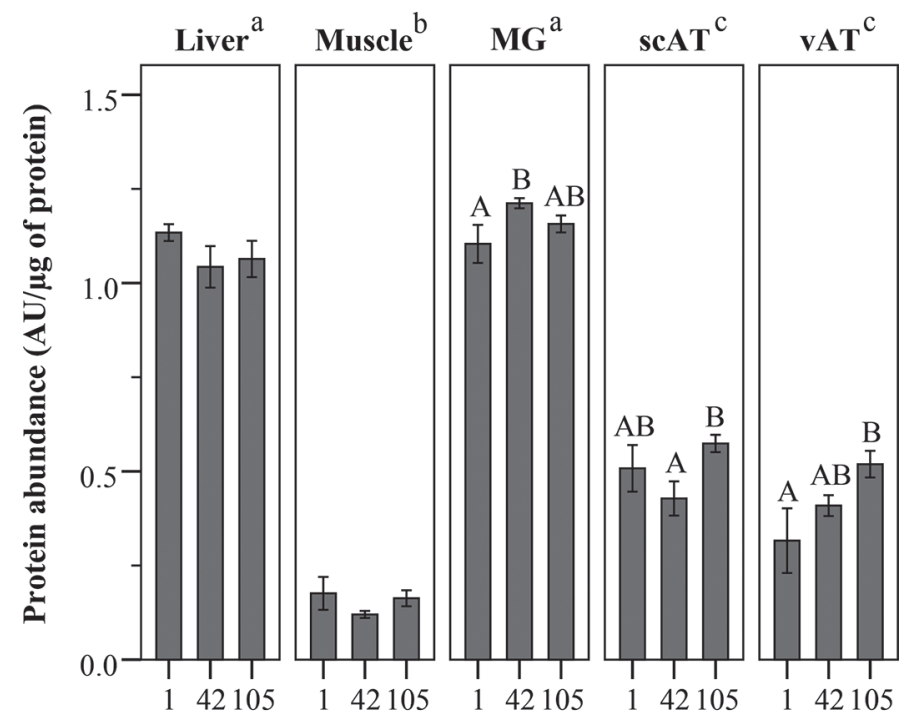

Days after parturition

Figure 6. Protein abundance [arbitrary units (AU)/ $\mu$ g of protein] of the branched-chain $\alpha$-keto acid dehydrogenase E1, $\alpha$ polypeptide (BCKDHA) in liver, skeletal muscle, mammary gland (MG), and subcutaneous (scAT) and visceral adipose tissue (vAT) of dairy cows on d $1(\mathrm{n}=5), 42(\mathrm{n}=10)$, and $105(\mathrm{n}=10)$ after parturition. Data are given as means \pm SEM. Different lowercase letters $(\mathrm{a}-\mathrm{c})$ indicate differences $(P<0.05)$ between tissues; different uppercase letters $(\mathrm{A}, \mathrm{B})$ indicate differences $(P<0.05)$ between time points within one tissue. 
kidney of mature sheep. More recently, Green et al. (2016) demonstrated the importance of BCKA oxidation in adipogenic differentiation and that inhibition of BCAA catabolism compromised adipogenesis. Moreover, it was assumed that, through linkages in the citric acid cycle, BCAA catabolism might regulate glyceroneogenesis as well as fatty acid oxidation in AT for the maintenance of lipid homeostasis (Kainulainen et al., 2013). The extent of a possible contribution of BCAA catabolism to milk fat synthesis is yet unclear.

During early lactation, bovine AT exhibits a pronounced metabolic activity (McNamara, 1991). Glutamate, resulting from $\mathrm{BCAA}$ deamination in $\mathrm{AT}$, may be used for the synthesis of NEAA, such as Ala and Gln (Tischler and Goldberg, 1980), providing important "N shuttles" between different tissues and therefore supporting lactogenic processes in the MG.

Initially avoiding hepatic degradation, BCAA or their metabolites may still be catabolized in the liver to some degree, most likely to maintain BCAA/BCKA homeostasis (Ananieva et al., 2017). Therefore, it could be assumed that liver tissue generally has a high $B C K D H$ mRNA expression. This expectation was only met by the findings for the $\beta$ subunit, but not for the $\alpha$ subunit of the BCKDH E1 component. Although $B C K D H A$ mRNA in liver was equally low in $\mathrm{MG}$ and

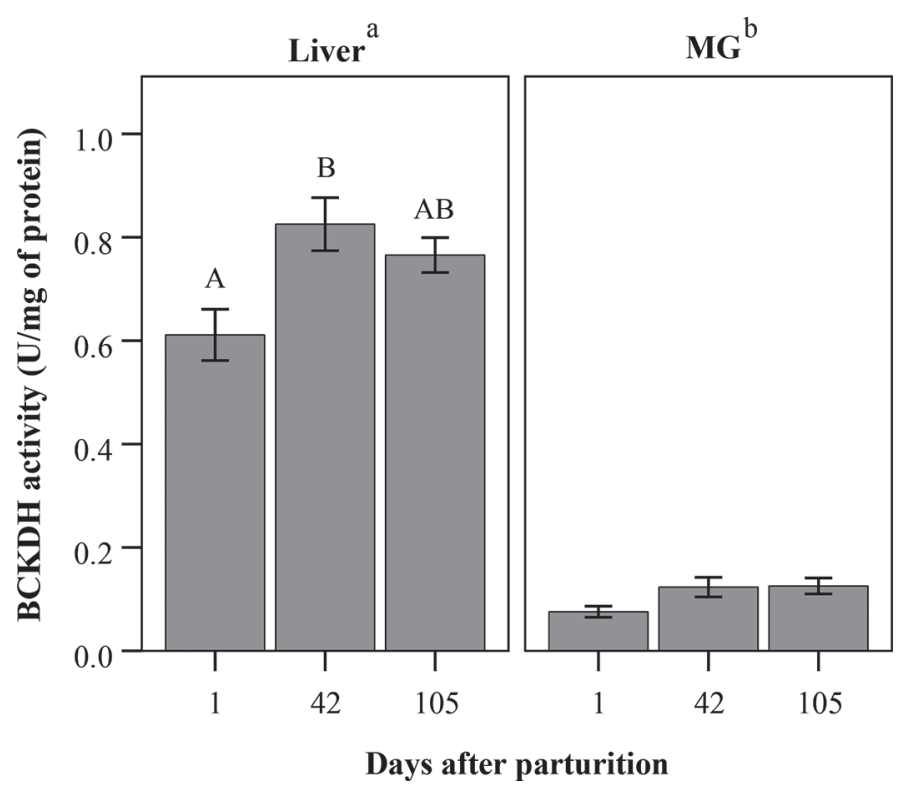

Figure 7. Enzyme activity of the branched-chain $\alpha$-keto acid dehydrogenase $(\mathrm{BCKDH})$ complex in liver and mammary gland (MG) of dairy cows on d $1(\mathrm{n}=5), 42(\mathrm{n}=10)$, and $105(\mathrm{n}=10)$ after parturition. Data are given as means \pm SEM. Different lowercase letters $(\mathrm{a}, \mathrm{b})$ indicate differences $(P<0.05)$ between tissues; different uppercase letters $(\mathrm{A}, \mathrm{B})$ indicate differences $(P<0.05)$ between time points within one tissue.
AT, $B C K D H B$ mRNA abundance was more than 5-fold greater in liver compared with all other tissues. Most studies in mammals focused on assessing the $\alpha$ subunit of the BCKDH E1 component (Harris et al., 1997; Herman et al., 2010; Nichols et al., 2016), assuming it to be one of the main subunits responsive to nutritional and hormonal influences and therefore regulating enzymatic activity. Until now, it has not been clear whether this also applies for the ruminant organism. The sole upregulation of $B C K D H B$ mRNA could imply that the $\beta$ subunit might also partake in the hepatic disposal of BCAA (or more specifically, BCKA) in dairy cows. Yet, in the current study, this could not be fully supported at the level of protein, as only a qualitative detection of BCKDHB protein was possible. Both $B C K D H A$ as well as $B C K D H B$ mRNA increased in MG and vAT during the course of the experiment, indicating a possible enhancement of BCKA oxidation in these tissues to meet the rising energetic and nutritional demands with progressing lactation. In partial support of this, DeSantiago et al. (1998) described a 10-fold increase of Leu oxidation in MG of rats in peak lactation in comparison to nonlactating rats. No data have been published yet regarding BCAA metabolism in AT of lactating individuals.

Highest BCKDHA protein abundance was observed in liver and MG, followed by AT, and lowest in muscle, suggesting a relatively low oxidative capacity of the latter tissue in dairy cows during early lactation. The actual changes of BCKDHA protein abundance with time in MG and AT were rather negligible and did not follow any regular patterns; therefore, interpretation is not reasonable. Based on calculations of isotopic transfers in Lapierre et al. (2002), liver contributes only 3 to $19 \%$ to whole-body Leu oxidation compared with 31 to $37 \%$ for the portal-drained viscera in lactating dairy cows. However, the high capacity for hepatic oxidation of BCKA enabled through increased BCKDH abundance (and activity), as shown in our study, could be a counter-regulatory response to the quantitatively low liver net flux of BCAA and their metabolites, ensuring all possible substrates or energy sources be used for milk production. Moreover, the possibility of hepatic BCKA degradation could be seen as a form of preventive measure, only truly affecting hepatic fluxes in case of perilously high BCKA concentrations in the circulation, which under regular feeding regimens would naturally be avoided.

Likewise, the observed elevated BCKDH protein abundance in MG may facilitate irreversible degradation of BCAA deamination products and, therefore, provide additional energy for lactation; however, oxidation might vary with AA supply (Bequette et 
al., 1996a). In a different study, Bequette et al. (2002) described a higher oxidation rate of 4-methyl 2-oxopentanoate (MOP; keto-leucine) in the hind leg compared with MG of lactating goats. For the hind leg, however, the uptake of MOP was negative throughout the whole experiment, indicating endogenous MOP production for which those authors did not correct. Further, it has already been hypothesized that, during early lactation, ovine skeletal muscle is less responsive to both AA supplies (Tauveron et al., 1994) and insulin (Debras et al., 1989) compared with mid lactation, ensuring optimal availability of nutrients for lactation. A downregulation of BCAA degrading enzymes in muscle may therefore support the flux of BCAA (and their intermediates) toward the MG.

Activity of the BCKDH complex is regulated through phosphorylation (inactivation) and dephosphorylation (activation) of the E1 $\alpha$ subunit of the enzyme complex by a specific kinase (branched-chain $\alpha$-keto acid dehydrogenase kinase; EC 2.7.11.4) and phosphatase (branched-chain $\alpha$-keto acid dehydrogenase phosphatase; EC 3.1.3.16), respectively (Shimomura et al., 1990; Lu et al., 2009). In mature sheep, BCKDH is almost fully activated in the liver (Goodwin et al., 1987); hence, the ability of liver to respond acutely to metabolic events is limited and probably requires the synthesis of additional enzyme protein (Lapierre et al., 2002). On the contrary, in tissues such as skeletal muscle or AT, most of the BCKDH enzyme is inactive (Goodwin et al., 1987; Papet et al., 1988) and thus acutely sensitive to metabolic regulators such as insulin, energy status, and BCAA supply (Aftring et al., 1986; Hutson, 1986). The presence of BCKDH in its inactive form might therefore explain the unquantifiable activities of the enzyme in muscle and AT in the present study. Moreover, a high ratio of BCAT to BCKDH activity in muscle, favoring the release of BCKA into the circulation instead of their oxidation, as well as a high BCKDH-to-BCAT activity ratio in liver, allowing for BCKA oxidation (Hutson et al., 2005), would both support a continuous exchange of metabolites between these tissues.

During lactation, the MG is prioritized in nutrient use over other peripheral tissues (Bauman and Currie, 1980), and BCAA uptake by the MG was shown to be enhanced in lactating ruminants (Davis et al., 1978; Guinard and Rulquin, 1994). Consequently, protein synthesis in other tissues, such as muscle, declines (Baracos et al., 1991), resulting in increased relative contributions from the splanchnic tissues and MG to whole-body protein metabolism (Lapierre et al., 2002). Our results have shown that, despite the similarities in protein abundance in liver and MG, the corresponding $\mathrm{BCKDH}$ enzyme activity was only increased in liver, probably due to physiological stimuli regulating BCAA homeostasis or distinct tissue-specific responses to insulin. This form of decoupling might lead to a greater amount of interorgan shuttling of BCAA and their metabolites, which could allow for a more differential regulation and support BCAA conservation. Accordingly, the lower enzyme activity observed in the $\mathrm{MG}$ possibly directs the flux of BCAA (or rather their keto acids) to de novo protein synthesis as EAA and NEAA.

However, having measured specific enzyme activity (i.e., enzyme activity related to protein mass) under saturated substrate conditions ex vivo may not necessarily reflect the real activity within the cell. Therefore, the applicability of results obtained to in vivo systems might have some limitations, particularly because data on BCAA/BCKA tissue transfers are missing in our study. However, for the investigated tissues, BCKDH activity was measured under the same conditions; thus, a tissue-wise comparison of the enzymatic capacity for BCKA oxidation is still possible.

Nevertheless, given that BCKDH catalyzes the ratelimiting step in the BCAA catabolic pathway, alterations in enzyme activity may play an important role in determining the metabolic fate of BCAA; that is, whether these AA should be used as energy sources or, eventually, for the synthesis of (milk) protein during lactation.

\section{CONCLUSIONS}

Our data reveal that the key enzymes of BCAA catabolism vary in their contribution to BCAA degradation in major metabolic tissues of dairy cows. The greatest abundance of BCATm mRNA in both scAT and vAT as compared with other tissues may indicate that $\mathrm{AT}$ is an important contributor in the reversible degradation of BCAA to BCKA during early lactation. Reduced BCKDH enzyme activity in $\mathrm{MG}$ along with no measurable activity in AT and muscle may favor sparing of BCAA for the synthesis of the different milk components, including NEAA. Among the tissues studied, liver had high BCKDH abundance and the greatest enzyme activity. Based on previous flux studies in ruminants and our observations, these data might suggest a counter-regulatory mechanism employed by liver during early lactation. It is also likely that BCKDH is fully activated in the liver and, hence, the ability of liver to respond acutely to metabolic events might be limited. Given that protein abundance may not proportionally correspond to mRNA, future research that includes protein abundance and activity of $\operatorname{BCAT}(\mathrm{m})$ may provide additional clues to the involvement of the studied tissues in BCAA metabolism in dairy cows. 


\section{ACKNOWLEDGMENTS}

This study is based upon earlier projects supported by the German Research Foundation (PAK 286/1, DA 558/5-1). The authors thank co-workers at the Institute of Animal Nutrition and the Experimental Station of the Friedrich-Loeffler-Institut (FLI) in Brunswick, Germany, for performing the experiment. Special gratitude is dedicated to Inga Hofs, Isabella Israel, and Barbara Heitkönig (Institute of Animal Science, Physiology and Hygiene Unit, University of Bonn) as well as Anke Ernst (Department of Nutrition and Food Sciences, Nutritional Physiology, University of Bonn) for their excellent laboratory assistance.

\section{REFERENCES}

Aftring, R. P., K. P. Block, and M. G. Buse. 1986. Leucine and isoleucine activate skeletal muscle branched-chain alpha-keto acid dehydrogenase in vivo. Am. J. Physiol. 250:E599-E604.

Ananieva, E. A., C. G. van Horn, M. R. Jones, and S. M. Hutson. 2017. Liver BCATm transgenic mouse model reveals the important role of the liver in maintaining BCAA homeostasis. J. Nutr. Biochem. 40:132-140.

Appuhamy, J. A. D. R. N., N. A. Knoebel, W. A. D. Nayananjalie, J. Escobar, and M. D. Hanigan. 2012. Isoleucine and leucine independently regulate mTOR signaling and protein synthesis in MAC-T cells and bovine mammary tissue slices. J. Nutr. 142:484-491.

Baracos, V. E., J. Brun-Bellut, and M. Marie. 1991. Tissue protein synthesis in lactating and dry goats. Br. J. Nutr. 66:451-465.

Bauman, D. E., and W. B. Currie. 1980. Partitioning of nutrients during pregnancy and lactation: A review of mechanisms involving homeostasis and homeorhesis. J. Dairy Sci. 63:1514-1529.

Bequette, B. J., F. R. Backwell, J. C. MacRae, G. E. Lobley, L. A. Crompton, J. A. Metcalf, and J. D. Sutton. 1996a. Effect of intravenous amino acid infusion on leucine oxidation across the mammary gland of the lactating goat. J. Dairy Sci. 79:2217-2224.

Bequette, B. J., C. E. Kyle, L. A. Crompton, S. E. Anderson, and M. D. Hanigan. 2002. Protein metabolism in lactating goats subjected to the insulin clamp. J. Dairy Sci. 85:1546-1555.

Bequette, B. J., J. A. Metcalf, D. Wray-Cahen, F. C. Backwell, J. D. Sutton, M. A. Lomax, J. C. MacRae, and G. E. Lobley. 1996b. Leucine and protein metabolism in the lactating dairy cow mammary gland: Responses to supplemental dietary crude protein intake. J. Dairy Res. 63:209-222.

Bergen, W. G., J. R. Busboom, and R. A. Merkel. 1988. Leucine degradation in sheep. Br. J. Nutr. 59:323-333.

Bustin, S. A., V. Benes, J. A. Garson, J. Hellemans, J. Huggett, M. Kubista, R. Mueller, T. Nolan, M. W. Pfaffl, and G. L. Shipley. 2009. The MIQE guidelines: Minimum information for publication of quantitative real-time PCR experiments. Clin. Chem. 55:611622 .

Calder, P. C. 2006. Branched-chain amino acids and immunity. J. Nutr. 136:288S-293S.

Cant, J. P., E. J. DePeters, and R. L. Baldwin. 1993. Mammary amino acid utilization in dairy cows fed fat and its relationship to milk protein depression. J. Dairy Sci. 76:762-774.

Davis, S. R., R. Bickerstaffe, and D. S. Hart. 1978. Amino acid uptake by the mammary gland of the lactating ewe. Aust. J. Biol. Sci. 31:123-132.

Debras, E., J. Grizard, E. Aina, S. Tesseraud, C. Champredon, and M. Arnal. 1989. Insulin sensitivity and responsiveness during lactation and dry period in goats. Am. J. Physiol. 256:E295-E302.

DeSantiago, S., N. Torres, and A. R. Tovar. 1998. Leucine catabolism in mammary tissue, liver and skeletal muscle of dam rat during lactation and weaning. Arch. Med. Res. 29:25-32.
European Council. 1986. Council Directive of 24 November 1986 on the approximation of laws, regulations and administrative provisions of the Member States regarding the protection of animals used for experimental and other scientific purposes (86/609/EEC). Off. J. L 358:1-28.

Faure, M., F. Glomot, and I. Papet. 2001. Branched-chain amino acid aminotransferase activity decreases during development in skeletal muscles of sheep. J. Nutr. 131:1528-1534.

Fürst, P., L. Pollack, T. A. Graser, H. Godel, and P. Stehle. 1990. Appraisal of four pre-column derivatization methods for the highperformance liquid chromatographic determination of free amino acids in biological materials. J. Chromatogr. 499:557-569.

GfE (German Society of Nutrition Physiology). 2001. Ausschuss für Bedarfsnormen der Gesellschaft für Ernährungsphysiologie. Nr. 8. Empfehlungen zur Energie- und Nährstoffversorgung der Milchkühe und Aufzuchtrinder (Recommendations of energy and nutrient supply for dairy cows and breeding cattle). DLG-Verlag, Frankfurt am Main, Germany.

Goodwin, G. W., W. Gibboney, R. Paxton, R. A. Harris, and J. A. Lemons. 1987. Activities of branched-chain amino acid aminotransferase and branched-chain 2-oxo acid dehydrogenase complex in tissues of maternal and fetal sheep. Biochem. J. 242:305.

Green, C. R., M. Wallace, A. S. Divakaruni, S. A. Phillips, A. N. Murphy, T. P. Ciaraldi, and C. M. Metallo. 2016. Branched-chain amino acid catabolism fuels adipocyte differentiation and lipogenesis. Nat. Chem. Biol. 12:15-21.

Grummer, R. R. 1995. Impact of changes in organic nutrient metabolism on feeding the transition dairy cow. J. Anim. Sci. 73:28202833.

Guinard, J., and H. Rulquin. 1994. Effect of graded levels of duodenal infusions of casein on mammary uptake in lactating cows. 2. Individual amino acids. J. Dairy Sci. 77:3304-3315.

Harper, A. E., R. Miller, and K. P. Block. 1984. Branched-chain amino acid metabolism. Annu. Rev. Nutr. 4:409-454.

Harris, R. A., J. W. Hawes, K. M. Popov, Y. Zhao, Y. Shimomura, J. Sato, J. Jaskiewicz, and T. D. Hurley. 1997. Studies on the regulation of the mitochondrial $\alpha$-ketoacid dehydrogenase complexes and their kinases. Adv. Enzyme Regul. 37:271-293.

Herman, M. A., P. She, O. D. Peroni, C. J. Lynch, and B. B. Kahn. 2010. Adipose tissue branched chain amino acid (BCAA) metabolism modulates circulating BCAA levels. J. Biol. Chem. 285:11348-11356.

Hutson, S. M. 1986. Branched chain alpha-keto acid oxidative decarboxylation in skeletal muscle mitochondria. Effect of isolation procedure and mitochondrial delta pH. J. Biol. Chem. 261:4420-4425.

Hutson, S. M., A. J. Sweatt, and K. F. LaNoue. 2005. Branched-chain amino acid metabolism: Implications for establishing safe intakes. J. Nutr. 135:1557S-1564S

Kainulainen, H., J. J. Hulmi, and U. M. Kujala. 2013. Potential role of branched-chain amino acid catabolism in regulating fat oxidation. Exerc. Sport Sci. Rev. 41:194-200.

Lapierre, H., J. P. Blouin, J. F. Bernier, C. K. Reynolds, P. Dubreuil, and G. E. Lobley. 2002. Effect of supply of metabolizable protein on whole body and splanchnic leucine metabolism in lactating dairy cows. J. Dairy Sci. 85:2631-2641.

Larsen, M., C. Galindo, D. R. Ouellet, G. Maxin, N. B. Kristensen, and H. Lapierre. 2015. Abomasal amino acid infusion in postpartum dairy cows: Effect on whole-body, splanchnic, and mammary amino acid metabolism. J. Dairy Sci. 98:7944-7961.

Larsen, M., H. Lapierre, and N. B. Kristensen. 2014. Abomasal protein infusion in postpartum transition dairy cows: Effect on performance and mammary metabolism. J. Dairy Sci. 97:5608-5622.

Li, P., D. A. Knabe, S. W. Kim, C. J. Lynch, S. M. Hutson, and G. Wu. 2009. Lactating porcine mammary tissue catabolizes branched-chain amino acids for glutamine and aspartate synthesis. J. Nutr. 139:1502-1509.

Lu, G., H. Sun, P. She, J.-Y. Youn, S. Warburton, P. Ping, T. M. Vondriska, H. Cai, C. J. Lynch, and Y. Wang. 2009. Protein phosphatase $2 \mathrm{Cm}$ is a critical regulator of branched-chain amino acid catabolism in mice and cultured cells. J. Clin. Invest. 119:1678-1687. 
MacRae, J. C., L. A. Bruce, D. S. Brown, and A. G. Calder. 1997. Amino acid use by the gastrointestinal tract of sheep given lucerne forage. Am. J. Physiol. 273:G1200-G1207.

McNamara, J. P. 1991. Regulation of adipose tissue metabolism in support of lactation. J. Dairy Sci. 74:706-719.

Meglia, G. E., A. Johannisson, S. Agenäs, K. Holtenius, and K. P. Waller. 2005. Effects of feeding intensity during the dry period on leukocyte and lymphocyte sub-populations, neutrophil function and health in periparturient dairy cows. Vet. J. 169:376-384.

Mepham, T. B. 1982. Amino acid utilization by lactating mammary gland. J. Dairy Sci. 65:287-298.

Metcalf, J. A., D. Wray-Cahen, E. E. Chettle, J. D. Sutton, D. E. Beever, L. A. Crompton, J. C. MacRae, B. J. Bequette, and F. R. Backwell. 1996. The effect of dietary crude protein as protected soybean meal on mammary metabolism in the lactating dairy cow. J. Dairy Sci. 79:603-611.

Nakai, N., R. Kobayashi, K. M. Popov, R. A. Harris, and Y. Shimomura. 2000. Determination of branched-chain $\alpha$-keto acid dehydrogenase activity state and branched-chain $\alpha$-keto acid dehydrogenase kinase activity and protein in mammalian tissues. Methods Enzymol. 324:48-62.

Nichols, K., J. J. M. Kim, M. Carson, J. A. Metcalf, J. P. Cant, and J. Doelman. 2016. Glucose supplementation stimulates peripheral branched-chain amino acid catabolism in lactating dairy cows during essential amino acid infusions. J. Dairy Sci. 99:1145-1160.

Papet, I., N. Lezebot, F. Barre, M. Arnal, and A. E. Harper. 1988. Influence of dietary leucine content on the activities of branchedchain amino acid aminotransferase (EC 2.6. 1.42) and branchedchain $\alpha$-keto acid dehydrogenase (EC 1.2. 4.4) complex in tissues of preruminant lambs. Br. J. Nutr. 59:475-483.

Pell, J. M., E. M. Caldarone, and E. N. Bergman. 1986. Leucine and $\alpha$-ketoisocaproate metabolism and interconversions in fed and fasted sheep. Metabolism 35:1005-1016.

Raggio, G., S. Lemosquet, G. E. Lobley, H. Rulquin, and H. Lapierre. 2006. Effect of casein and propionate supply on mammary protein metabolism in lactating dairy cows. J. Dairy Sci. 89:4340-4351.

Raggio, G., D. Pacheco, R. Berthiaume, G. E. Lobley, D. Pellerin, G. Allard, P. Dubreuil, and H. Lapierre. 2004. Effect of level of metabolizable protein on splanchnic flux of amino acids in lactating dairy cows. J. Dairy Sci. 87:3461-3472.

Saremi, B., A. Al-Dawood, S. Winand, U. Müller, J. Pappritz, D. von Soosten, J. Rehage, S. Dänicke, S. Häussler, M. Mielenz, and H. Sauerwein. 2012a. Bovine haptoglobin as an adipokine: Serum concentrations and tissue expression in dairy cows receiving a conjugated linoleic acids supplement throughout lactation. Vet. Immunol. Immunopathol. 146:201-211.

Saremi, B., H. Sauerwein, S. Dänicke, and M. Mielenz. 2012b. Technical note: Identification of reference genes for gene expression studies in different bovine tissues focusing on different fat depots. J. Dairy Sci. 95:3131-3138.
Shimomura, Y., N. Nanaumi, M. Suzuki, K. M. Popov, and R. A. Harris. 1990. Purification and partial characterization of branchedchain $\alpha$-ketoacid dehydrogenase kinase from rat liver and rat heart. Arch. Biochem. Biophys. 283:293-299.

Suryawan, A., J. W. Hawes, R. A. Harris, Y. Shimomura, A. E. Jenkins, and S. M. Hutson. 1998. A molecular model of human branchedchain amino acid metabolism. Am. J. Clin. Nutr. 68:72-81.

Sweatt, A. J., M. Wood, A. Suryawan, R. Wallin, M. C. Willingham, and S. M. Hutson. 2004. Branched-chain amino acid catabolism: Unique segregation of pathway enzymes in organ systems and peripheral nerves. Am. J. Physiol. Endocrinol. Metab. 286:E64-E76.

Tauveron, I., D. Larbaud, C. Champredon, E. Debras, S. Tesseraud, G. Bayle, Y. Bonnet, P. Thieblot, and J. Grizard. 1994. Effect of hyperinsulinemia and hyperaminoacidemia on muscle and liver protein synthesis in lactating goats. Am. J. Physiol. 267:E877E885.

Thivierge, M. C., D. Petitclerc, J. F. Bernier, Y. Couture, and H. Lapierre. 2002. Variations in mammary protein metabolism during the natural filling of the udder with milk over a 12 -h period between two milkings: Leucine Kinetics. J. Dairy Sci. 85:2974-2985.

Tischler, M. E., and A. L. Goldberg. 1980. Leucine degradation and release of glutamine and alanine by adipose tissue. J. Biol. Chem 255:8074-8081.

von Soosten, D., R. Kramer, G. Jahreis, U. Meyer, G. Flachowsky, and S. Dänicke. 2013. Transfer of conjugated linoleic acids into different tissues of dairy cows. Arch. Anim. Nutr. 67:119-133.

von Soosten, D., U. Meyer, M. Piechotta, G. Flachowsky, and S. Dänicke. 2012. Effect of conjugated linoleic acid supplementation on body composition, body fat mobilization, protein accretion, and energy utilization in early lactation dairy cows. J. Dairy Sci 95:1222-1239.

von Soosten, D., U. Meyer, E. M. Weber, J. Rehage, G. Flachowsky, and S. Dänicke. 2011. Effect of trans-10, cis-12 conjugated linoleic acid on performance, adipose depot weights, and liver weight in early-lactation dairy cows. J. Dairy Sci. 94:2859-2870.

Wessels, A. G., H. Kluge, F. Hirche, A. Kiowski, A. Schutkowski, E. Corrent, J. Bartelt, B. König, and G. I. Stangl. 2016. High leucine diets stimulate cerebral branched-chain amino acid degradation and modify serotonin and ketone body concentrations in a pig model. PLoS One 11:e0150376.

Wohlt, J. E., J. H. Clark, R. G. Derrig, and C. L. Davis. 1977. Valine, leucine, and isoleucine metabolism by lactating bovine mammary tissue. J. Dairy Sci. 60:1875-1882.

Wray-Cahen, D., J. A. Metcalf, F. R. C. Backwell, B. J. Bequette, D. S. Brown, J. D. Sutton, and G. E. Lobley. 1997. Hepatic response to increased exogenous supply of plasma amino acids by infusion into the mesenteric vein of Holstein-Friesian cows in late gestation. Br. J. Nutr. 78:913-930. 